\title{
ALICJA PALUCH
}

Uniwersytet Opolski

ORCiD: 0000-0002-4310-2440

\section{HENRYK SPUSTEK}

Uniwersytet Opolski

ORCiD: 0000-0001-7594-1866

\section{Terroryzm — zjawisko pochodne wojny}

\author{
Wojna jest ojcem wszystkich rzeczy. \\ Heraklit z Efezu \\ ok. $540-480$ p.n.e.
}

\section{Wprowadzenie}

Wojna, podobnie jak sama walka, wpisana jest w rozwój ludzkości od wieków. Walka istnieje w życiu człowieka jako naturalna forma jego zmagań z otaczającą go rzeczywistością. Nie jest ona zatem zjawiskiem z definicji negatywnym samym w sobie. Jest jedynie pewnym środkiem osiągania celu. Istota walki leży w jej przyczynie, celu i formie traktowania przeciwnika. Paradygmat walki obejmuje dwa sprzeczne spojrzenia: pierwsze mieszczące się w kategorii dramatu oraz drugie walki jako formy destrukcji. Stąd też wywodzą się dwa odmienne modele walki: model dynamiczny i model mechanistyczny ${ }^{1}$.

Model dynamiczny określa człowieka będącego mieszkańcem Ziemi jako gospodarza, który uważa za rzecz naturalną walkę o taki kształt rzeczywistości, jaki jest według niego właściwy. Człowiek traktuje Ziemię jako swoją Ojczyznę, dla której nie ma alternatywy; jego przeciwnikiem jest natura. Podobnie wygląda walka z drugim człowiekiem — tutaj obie strony przed walką mają rację; wygrywa racja

1 J. Nizińska, Walka ze soba a walka o siebie, [w:] A. Żuk, Konflikt a walka, Lublin 1996, s. 204-205. 
silniejszego, ale walka odbywa się zawsze z zachowaniem szacunku dla przeciwnika. Ma ona wymiar dramatu, jej aktorzy traktują siebie nawzajem podmiotowo. Model ten jednak stracił rację bytu wraz z zakończeniem okresu średniowiecza ${ }^{2}$.

Model mechanistyczny pojawił się wraz z rozwojem myśli, intelektu i technologii. Jest on zaprzeczeniem idei modelu dynamicznego i pozostaje w opozycji do wszystkich zdobyczy ludzkości powstałych w wyniku rozwoju intelektualnego człowieka. Strony walki traktują się mechanicznie: walka nie kończy się zwycięstwem jednej strony nad drugą, trwa aż do całkowitego unicestwienia przeciwnika. Model ten obejmuje swoim zakresem ludobójstwo i Holokaust, jak również degenerację procesu walki - terroryzm. Zależnie od wartości, jakie człowiek uznaje za słuszne (bądź są mu one narzucone), określa on sposób prowadzenia walki, wybierając jednocześnie rodzaj jej paradygmatu ${ }^{3}$. A zatem o wyborze modelu walki decyduje stopień świadomości człowieka w kwestii jego roli w rodzinie ludzkiej. Dlatego oczywiste jest, że w omawianym paradygmacie mieści się również pojęcie walki wewnętrznej, toczącej się w człowieku — walki dobra ze złem.

$\mathrm{Z}$ biegiem czasu katalog rodzajów wojen i sposobów walki rozszerzał się. Jednakże dwa główne modele walki — dynamiczny i mechanistyczny — pozostały niezmienne. Początkowo ginęły wielkie armie i całe narody. Wojna, która miała przynieść powszechny dobrobyt, odwieczny ład, zwycięstwo nad niewiernymi i wieczną sławę zwycięzcom, wprowadzała zwykle zamęt, powszechne wyniszczenie i była przyczyną następnych wojen. Każda wojna, niezależnie od celu, jaki jej przyświeca, jawi się jako gra o sumie ujemnej. Wszystkie strony uczestniczące $\mathrm{w}$ wojnie ponoszą straty, a w szczególności ci, którzy podlegają specjalnej ochronie w myśl zapisów Międzynarodowego Prawa Humanitarnego: ludność cywilna, społeczeństwa antagonistycznie do siebie nastawionych stron.

$\mathrm{Na}$ rysunku 1 przedstawiono dwa modele walki: dynamiczny i mechanistyczny. Model dynamiczny, walkę z poszanowaniem praw i zwyczajów wojny (w aspekcie militarnym), szacunkiem do strony przeciwnej (w aspekcie niemilitarnym, np. ekonomicznym, rozumiana jako gra konkurencyjna) obrazuje część A rysunku 1. Część B pokazuje model mechanistyczny. Terroryzm będący zjawiskiem towarzyszącym walce w sferze ekonomicznej i społecznej należy rozumieć jako pochodną działań militarnych. Wynika to z szerokiego wykorzystywania środków i metod militarnych przez grupy terrorystyczne.

Współczesny obraz zwaśnionego świata pozwala na stwierdzenie, że dominującym modelem walki stał się niestety model mechanistyczny. Dzieje się tak między innymi za sprawą terroryzmu.

W niniejszym artykule pokazano terroryzm w trzech odsłonach, które nazwano aspektami: militarnym, ekonomicznym i społecznym.

\footnotetext{
2 Ibidem, s. 207-208.

3 Ibidem, s. 209.
} 

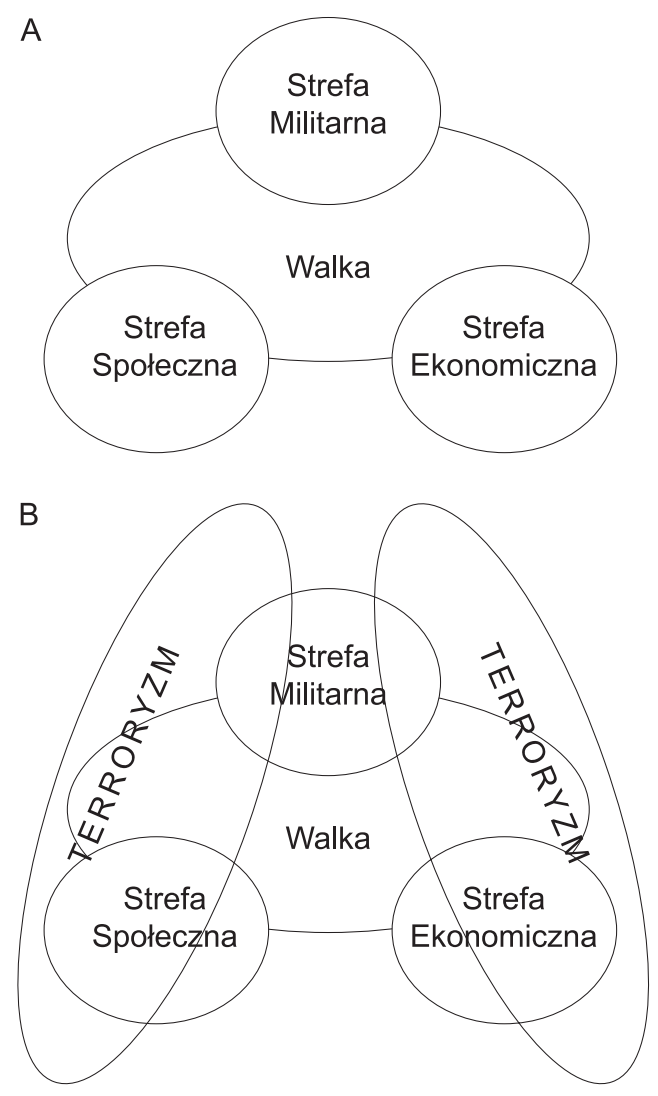

Rys. 1. Dwa modele walki a terroryzm

Źródło: opracowanie własne.

\section{Zjawiska pochodne wojny}

\section{Aspekt militarny — poglądy na współczesną wojnę}

Zasady prowadzenia wojny współcześnie znacząco się zmieniły. Wojna w wymiarze klasycznym, rozumiana jako forma konfliktu zbrojnego o prewencji politycznej ${ }^{4}$, została wzbogacona o niekonwencjonalne środki oddziaływania. W ostatnim czasie upowszechniła się koncepcja wojny hybrydowej będąca według wielu uczonych konglomeratem wojny klasycznej i wojny niekonwencjonalnej — działań terrorystycznych, partyzanckich oraz działalności przestępczej, w której działania mają charakter zarówno symetryczny, jak i asymetryczny (prowadzone równocześ-

${ }^{4}$ K. Drabik, Natura wojny w poglądach filozofów realistów, „Kwartalnik Bellona” 2013, nr 3 (674), s. 118. 
nie podczas konfliktu), a zaangażowanymi w nią podmiotami ${ }^{5}$ są zarówno państwa, jak również aktorzy niepaństwowi. Jak twierdzi Jacek Reginia-Zacharski, w wojnie tego typu ,przynajmniej jeden z przeciwników wykazuje niedookreślony, amorficzny i zmienny status prawny, co uniemożliwia bądź poważnie utrudnia klasyfikację rodzaju konfliktu i zastosowanie w nim adekwatnego mechanizmu prawnego"6. Podmioty te mają charakter zdecentralizowany i rozproszony, dlatego też możliwość przeprowadzenia ataku odwetowego jest znacząco utrudniona lub niemożliwa. Komplementarnym aspektem opisywanych działań jest prowadzenie operacji informacyjnych, „skoordynowanych i zsynchronizowanych w celu uzyskania zakładanych rezultatów w zachowaniach, przekonaniach i postawach wybranych grup społecznych"7. Mogą one stanowić podstawę „rozpoczęcia, prowadzenia i podtrzymywania wojny hybrydowej, aż do osiągnięcia zamierzonego stanu końcowego - z reguły zaczyna się o wiele wcześniej niż działania hybrydowe"8. Obecnie głównym obszarem prowadzenia wojny informacyjnej jest płaszczyzna wirtualna (tzw. cyberwojna). Jest ona wykorzystywana szczególnie przez terrorystów, daje bowiem możliwość zredukowania asymetrii militarnej asymetrią zastraszenia społecznego ${ }^{9}$ - w zasięgu zarówno regionalnym, jak i międzynarodowym (wojna psychologiczna). Pozwala także na inspirowanie, organizowanie i finansowanie funkcjonowania i rozwoju ugrupowań radykalnych i ekstremistycznych (m.in. politycznych, religijnych) w państwie nieprzyjaciela. Jak wskazuje Bolesław Balcerowicz, ,uderzenie w cybersferze stanowi niewątpliwie atrakcyjną opcję dla krajów słabszych, podmiotów pozapaństwowych dla strategii asymetrycznych" 10 . Desygnatami wojny hybrydowej są także inne elementy z zakresu niemilitarnych narzędzi prowadzenia konfliktu. Do najpopularniejszych zalicza się środki bezpośredniego oddziaływania na ludność cywilną, tj. wprowadzanie sankcji ekonomicznych w postaci embarga lub wysokich ceł produktów importowanych z państwa, wobec którego prowadzone są działania hybrydowe lub z krajów udzielających mu wsparcia. Stosowane są również groźby odcięcia dostaw surowców strategicznych. Istotną rolę ogrywa także spotęgowana aktywność wywiadowcza obcych służb na terytorium atakowanego państwa, których zadaniem jest gromadzenie informacji, budowa siatek wywiadowczo-sabotażowych oraz prowadzenie zintensyfikowanych

${ }^{5}$ Według J. Reginia-Zacharskiego ,głównym elementem definiującym wojnę hybrydową jako zjawisko międzynarodowe powinna być analiza przede wszystkim podmiotu zaangażowanego w działania wojenne (beligeranta), a nie metod stosowanych w walce (boju)". J. Reginia-Zacharski, Ukraina 2014-2015: Wojna (nie) hybrydowa, „Zeszyty Naukowe AON”2015, nr 3 (100), s. 33.

6 Ibidem, s. 40.

${ }^{7}$ M. Wrzosek, Działania psychologiczne w konfliktach nowego wieku, „Kwartalnik Bellona” 2016, nr 2 (685), s. 20.

${ }^{8}$ B. Pac, Integracja wojny informacyjnej $i$ hybrydowej $w$ konfliktach międzynarodowych, „Kwartalnik Bellona” 2016, nr 1 (684), s. 76.

9 M. Fryc, Wojna - wspótczesne oblicze, Toruń 2009, s. 59.

10 B. Balcerowicz, Czym jest współczesna wojna?, s. 15, http://files.pwi.edu.pl/files/balcerowicz.doc (dostęp: 25.05.2017). 
działań w cyberprzestrzeni, mających na celu niszczenie struktury i zasobów państwa. Kluczowe znaczenie mają także wielokierunkowe działania dyplomatyczne polegające na dyskredytowaniu wizerunku państwa nieprzyjaciela oraz budowaniu politycznego lobby w organizacjach międzynarodowych w celu uniemożliwienia podjęcia czynności z ich strony ${ }^{11}$.

Katalog działań prowadzonych w ramach wojny hybrydowej został przedstawiony w formie graficznej na rysunku 2, przy zaznaczeniu, że nie jest on zamknięty, gdyż z biegiem czasu może ulec zarówno poszerzeniu, jak i modyfikacji pod względem dotychczasowych metod i technik stosowanych w taktyce wojennej.

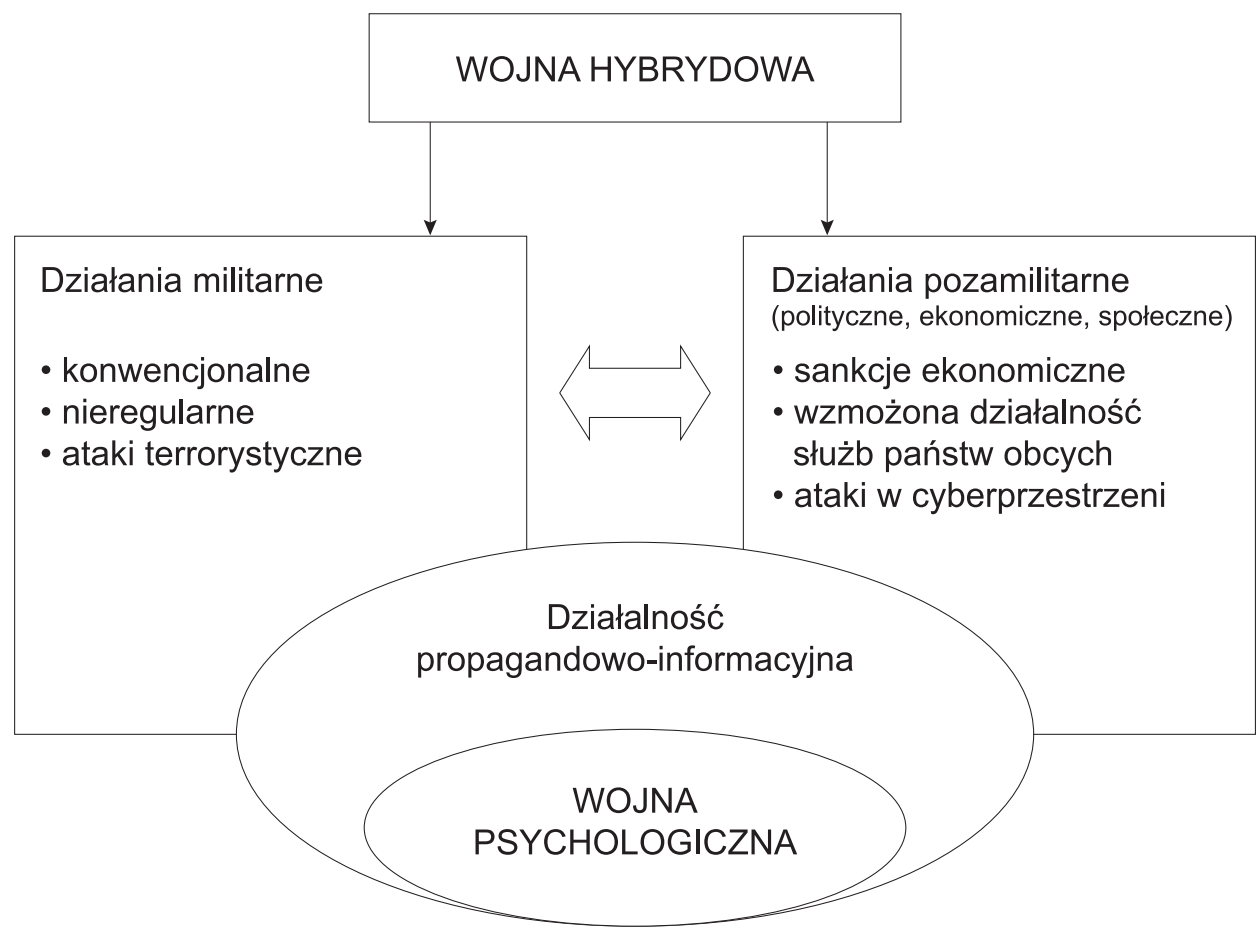

Rys. 2. Metody prowadzenia wojny hybrydowej

Źródło: opracowanie własne.

Celem wojny hybrydowej jest dążenie do „maksymalnej zbieżności i synchronizacji metod, środków oraz sposobów prowadzenia operacji militarnych i pozamilitarnych w celu zwiększenia efektu synergii ${ }^{12}$ " (multimodalne wykorzystanie

11 Ł. Skoneczny, Wojna hybrydowa - wyzwanie przyszłości? Wybrane zagadnienia, „Przegląd Bezpieczeństwa Wewnętrznego. Wojna hybrydowa. Wydanie specjalne” 2015, s. 47.

12 M. Wojnowski, Mit ,wojny hybrydowej”. Konflikt na terenie państwa ukraińskiego w świetle rosyjskiej myśli wojskowej XIX-XXI wieku, „Przegląd Bezpieczeństwa Wewnętrznego. Wojna hybrydowa. Wydanie specjalne" 2015, s. 9. 
sił w tej samej przestrzeni ${ }^{13}$ ), prowadzące do szybszego osiągania celów przez potencjalnych adwersarzy, ekonomizujących koszty konfliktów zbrojnych. Zostało to zobrazowane na rysunku 3 .

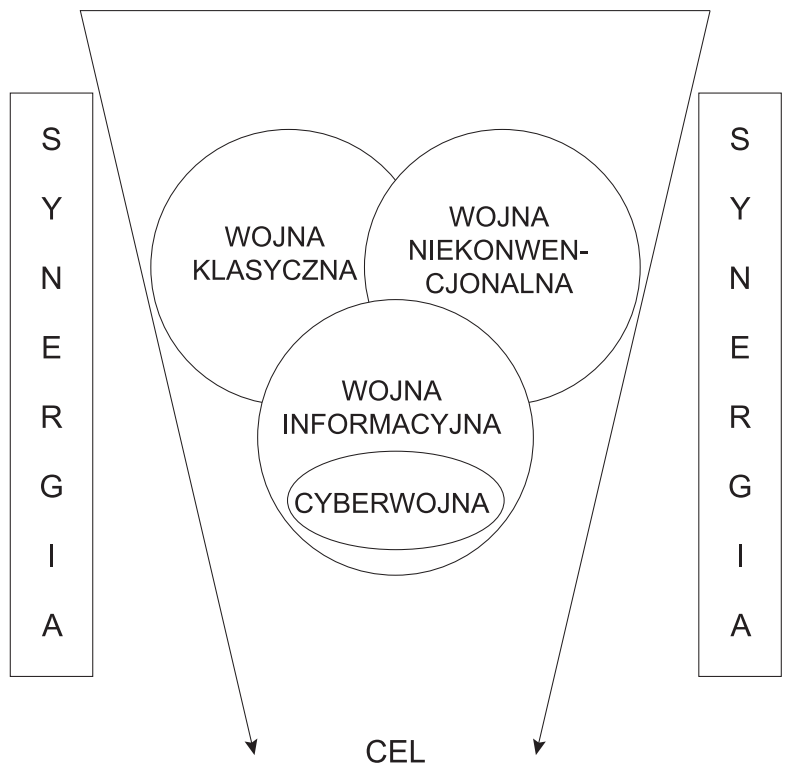

Rys. 3. Koncepcja wojny hybrydowej

Źródło: opracowanie własne.

Współczesne wojny charakteryzuje szeroko rozumiana asymetria o kilku potencjalnych formach. Można mówić o asymetrii:

— klasycznej,

— nieklasycznej,

— zaangażowanej,

— cywilizacyjno-kulturowej,

- technologicznej,

- systemowej ${ }^{14}$.

Klasyczne rozumienie asymetrii wiąże się ze zjawiskiem osiągania przewagi w walce militarnej, uzyskanej poprzez niewspółmiernie rozwinięty potencjał bojowy jednej ze stron w stosunku do strony przeciwnej (przy założeniu, że w konflikcie zbrojnym uczestniczą jedynie dwie antagonistyczne strony). Klasyczna asymetria ma swoje odwzorowanie w geometrii euklidesowej. Nieklasyczne rozumienie asymetrii wiąże się ze współczesną wizją wojny, w której często biorą udział strony dysponujące nieporównywalnymi siłami w sensie klasycznym.

13 J. Reginia-Zacharski, op. cit., s. 40.

14 J. Lasota, Aspekty asymetrii w sztuce wojennej, „Kwartalnik Bellona” 2014, nr 2 (677), s. $107-108$. 
Typowym przykładem asymetrii nieklasycznej jest tzw. wojna z terroryzmem. Pozostałe wymienione rodzaje asymetrii są ściśle powiązane z sobą w sensie asymetrii nieklasycznej. Dzieje się tak za sprawą podmiotów uczestniczących we współczesnych działaniach wojennych. Skonfliktowane strony kierują się diametralnie inną filozofią walki, co związane jest $\mathrm{z}$ wyznawaniem antagonistycznych systemów aksjologicznych. Ma to bezpośrednie przełożenie na sferę cywilizacyjno-kulturową. Z kolei asymetria technologiczna jest ściśle związana ze zjawiskami ekonomicznymi, co zostało rozwinięte w dalszej części niniejszego artykułu. Asymetrię systemową rozumie się jako starcie odmiennych systemów, różnych podmiotów (np. państwowych i niepaństwowych) ${ }^{15}$. Wizualizację asymetrii konfliktów zbrojnych przedstawiono na rysunku 4.

a)

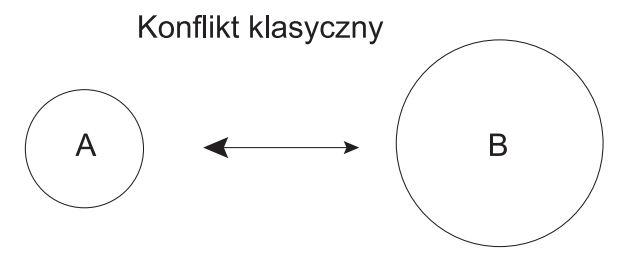

b)

Konflikt nieklasyczny

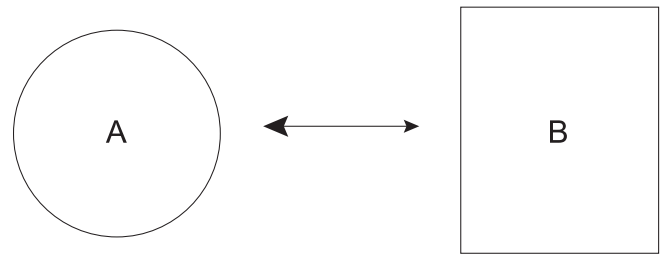

c)

Konflikt nieklasyczny

Synergia asymetrii

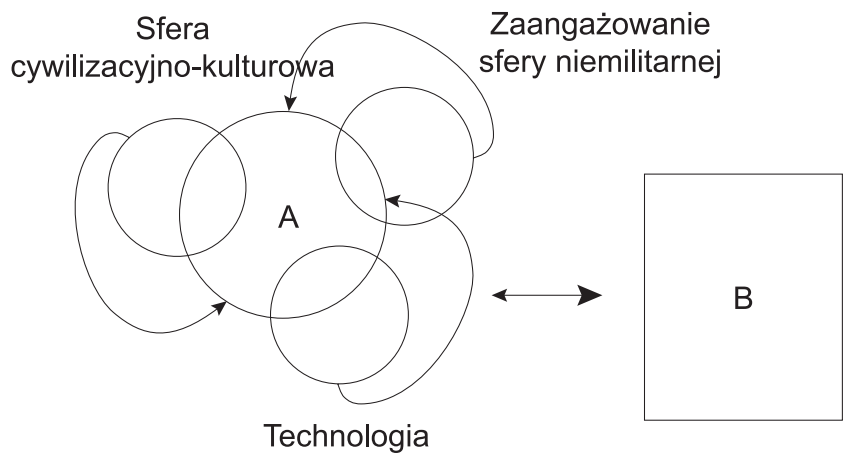

Rys. 4. Odmienne rozumienie asymetrii

Źródło: opracowanie własne.

15 Ibidem, s. 108. 


\section{Aspekt społeczny}

Jak już wspomniano we wprowadzeniu do niniejszego artykułu, działania wojenne dotykały i nadal najbardziej dotykają społeczeństwa skonfliktowanych stron. Należy jednak zauważyć, że obecnie ludność cywilna jest nie tylko „odbiorcą" skutków prowadzonych operacji (na ich terytorium - tj. głodu, epidemii, handlu ludźmi, sankcji ekonomicznych, wysiedlenia, czy też w otoczeniu międzynarodowym - niekontrolowanego napływu migrantów), lecz stała się głównym „narzędziem” prowadzenia wojny, umożliwiającym osiągnięcie celu głównego ${ }^{16}$, przy znacznie ograniczonym potencjale militarnym, w stosunkowo niedługim czasie i z efektem nieproporcjonalnie większym do zastosowanych sił i środków. Zjawisko to jest szczególnie widoczne w taktyce działań prowadzonych przez grupy terrorystyczne. Ich aktywność przestępcza bowiem nie jest wymierzona bezpośrednio w przeciwnika, lecz koncentruje się wokół danej społeczności, przyjmując wielowymiarowy charakter. Przede wszystkim rdzeniem działalności terrorystycznej jest społeczeństwo sieci (obszar, w którym kontrola komunikacji przez państwo jest znacznie ograniczona) — tu terroryści swobodnie mogą kierować i wpływać na zachowania i postawy użytkowników, prowadząc szeroką agitację, w konsekwencji doprowadzając do ich wyizolowania z grupy, a więc osiągając pierwszy cel pośredni, jakim jest dezintegrowanie mikro- i makrostruktury społecznej, i starając się wytrącać dalsze elementy ${ }^{17}$. Prowadzone są także działania zmierzające do zachwiania relacji wertykalnej w społeczeństwie, a więc na poziomie obywatel-państwo/organa państwowe, tj. podważanie legitymizacji sprawowanej władzy, ustalonych praw politycznych i gwarancji obywatelskich. Aktywność terrorystów skupia się także na infekowaniu obszaru relacji horyzontalnej — obywatel-obywatel — zaburzając wzajemne zaufanie, możliwość integracji i kooperacji, a także niszcząc tożsamość kulturową i religijną, chociażby poprzez zintensyfikowane migracje ludności muzułmańskiej niechętnej do asymilowania się z lokalną społecznością. Środkiem kolejnym i najbardziej destrukcyjnym dla bezpieczeństwa tak zbiorowego, jak i indywidualnego, jest stosowanie bezpośrednich środków przemocy i aktów terroru, jakimi są nasilające się ataki (lub ich groźby) z użyciem bomb, broni, niebezpiecznych narzędzi i pojazdów na ludność cywilną w miejscach jej największego skupienia w danym momencie, powodujące śmierć lub poważne zranienie. Efektem jest rozprzestrzenianie się powszechnego lęku, niepewności, braku poczucia bezpieczeństwa oraz zaburzenia codziennego funkcjonowania. Problem ten pogłębia dodatkowo widoczna bezradność służb i władz państwowych, brak kompleksowych rozwiązań

16 Przyjmuje się, że celem głównym jest „radykalna zmiana postaw politycznych, kulturowych, szerzej - społecznych, a w konsekwencji zmiana rzeczywistości w imię określonej idei”. J. Gryz, Terroryzm międzynarodowy jako zjawisko społeczne w poczatkach XXI wieku, „Zeszyty Naukowe AON" 2016, nr 1 (102), s. 5.

17 Ibidem, s. 7. 
i strategii przeciwdziałania podobnym zdarzeniom w przyszłości. Reasumując, można stwierdzić, że „współczesny terroryzm międzynarodowy występuje w ramach społeczeństw, przeciwko społeczeństwom oraz dla określonych społeczności" "18; posługuje się on strategią pośrednią, w której bezpośrednio atakowany jest cel pośredni, a gdy nastąpi jego osiągnięcie, realizowany jest jednocześnie cel główny lub znaczna jego część 19 .

\section{Aspekt ekonomiczny}

Współczesne konflikty międzynarodowe diametralnie różnią się od minionych. Mają one charakter i przebieg odmienny, niż miało to miejsce wcześniej. Nawet gdy są to konflikty zbrojne, to u ich rzeczywistych podstaw bardzo często leżą cele gospodarcze lub ekonomiczne. Obok „wojny cywilizacji” (przepowiadanej już w XX wieku przez wielu futurystów, jako wojna XXI wieku) ma miejsce pewna odmiana wojny gospodarczej - wojny o mocno nadwyrężone zasoby mineralne. Walczące $\mathrm{z}$ sobą strony gromadzą zasoby wybranych surowców strategicznych - potrzebnych do produkcji środków walki i obrony ${ }^{20}$. Znaczenie pojęcia „surowiec strategiczny” jest stricte militarne, dlatego też szersze jego rozumienie znajduje swoje odbicie w pojęciu „surowiec krytyczny" ${ }^{21}$. Lista surowców krytycznych jest zmienna i związana z ich własnościami, zarówno mechanicznymi, jak również elektromagnetycznymi, oraz ściśle skorelowana z rozwojem technologicznym. Lista surowców krytycznych dla gospodarek współczesnej Unii Europejskiej powiększa się, natomiast zasoby tych surowców sukcesywnie maleją. Tendencja ta stała się bezpośrednią przyczyną powstania listy surowców krytycznych. Na rysunku 5 przedstawiono wartości wskaźników zastępowalności surowców zakwalifikowanych jako krytyczne w Unii Europejskiej. Wskaźnik zastępowalności jest liczbą z zakresu od 0 do 1 , przy czym wyższa wartość wskaźnika wskazuje na coraz mniejszą zastępowalność danego surowca. Analiza danych zawartych na rysunku 5 wskazuje, że wskaźnik zastępowalności zobrazowanych surowców zawiera się w przedziale od 0,6 do 1,0, a rozkład wartości tego wskaźnika jest równomierny.

18 Ibidem, s. 5.

19 K. Liedel, P. Piasecka, Wspótpraca międzynarodowa w zwalczaniu terroryzmu, Warszawa 2004, s. 20.

20 J. Szpakowski, Surowce strategiczne, [w:] Ekonomika obrony, red. W. Bednarek, Łódź 1994, s. 77.

21 Pojęcie szersze od pojęcia surowców strategicznych obejmuje zastosowania zarówno wojskowe, jak i cywilne: surowce niezbędne do produkcji wojskowej (lub cywilnej) niedostępne w kraju (patrz: W. Stankiewicz, Ekonomika wojenna, Warszawa 1970, s. 145-146.). W literaturze można również spotkać definicję surowców krytycznych mówiącą o tym, że do grupy tych surowców należy zaliczyć te, których brak lub niedobór może mieć większe ujemne konsekwencje niż brak innych surowców (S. Zieliński, Surowce mineralne, „Chemik” 2014, t. 68, nr 5, s. 431). 
Surowce krytyczne mają bardzo rozległe zastosowanie: od produkcji zbrojeniowej, po elektronikę, automatykę i technikę komputerową. Obecnie praktycznie nie ma dziedziny, w której nie wykorzystywano by ich specyficznych własności. Można tu wymienić: przemysł lotniczy, silniki i części do samolotów i samochodów, systemy naprowadzania, technologie satelitarne, silne magnesy, radary i sonary, monitory komputerowe, soczewki do kamer i smartfonów, przenośne urządzenia rentgenowskie i wiele innych.

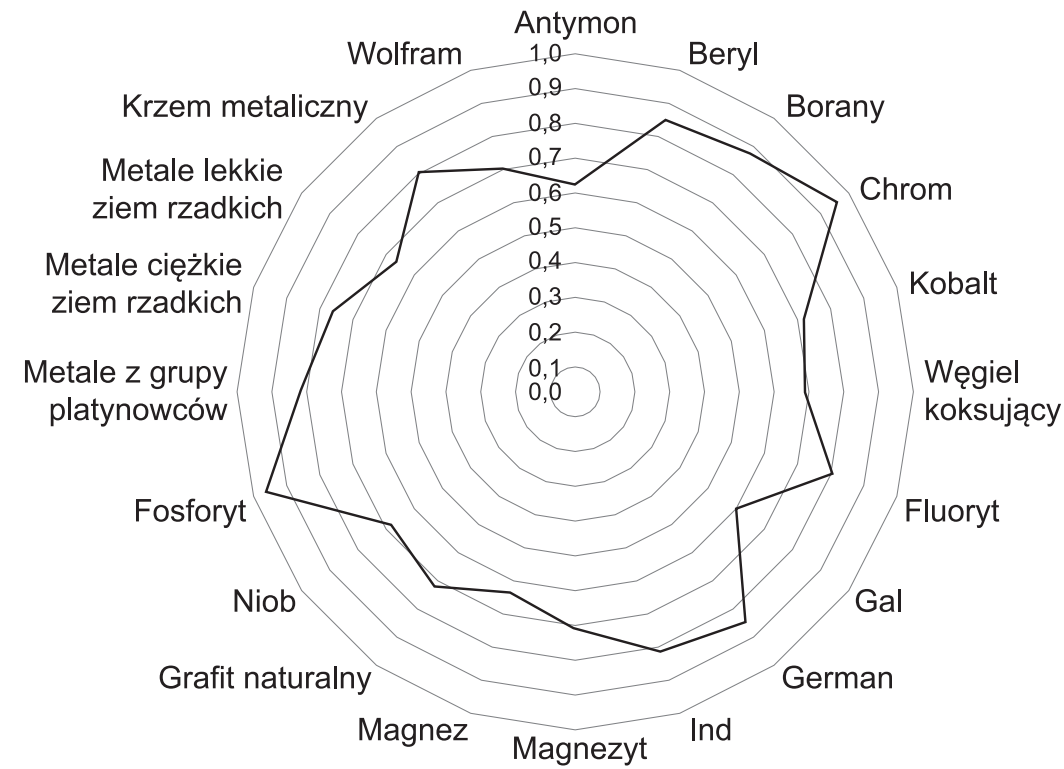

Rys. 5. Wskaźnik zastępowalności dla minerałów grupy krytycznej

Źródło: opracowano na podstawie Komunikatu Komisji do Parlamentu Europejskiego, Rady, Europejskiego Komitetu Ekonomiczno-Spotecznego i komitetu regionów z dnia 26.05.2014 roku, w sprawie przegladu surowców krytycznych dla UE $i$ wdrażania inicjatywy na rzecz surowców, Bruksela, baza aktów prawnych Unii Europejskiej, COM/2014/0297 final z dnia 26 maja 2014 roku, https://eur-lex.europa.eu/legal-content/PL/TXT/?uri=COM:2014:0297:FIN (dostęp: 20.04.2017).

Rozwój nowych technologii (aczkolwiek pozytywny w swoim przesłaniu) jest nierozerwalnie związany z eksploatacją nieodnawialnych złóż mineralnych. Perspektywa szybkiego wyczerpania się tych złóż niesie uzasadnione obawy społeczne. Stanowi to negatywną stronę postępu technologicznego i jednocześnie rodzi nowe zagrożenia, $w$ tym zagrożenia natury terrorystycznej. Ważne miejsce surowców krytycznych w sferze gospodarczej i ekonomicznej państwa determinuje zatem ich ścisły związek ze zjawiskiem terroryzmu. Rywalizacja w zakresie pozyskiwania przez państwa zasobów surowców krytycznych, gromadzenie zapasów surowcowych i walka rynkowa o ich dostęp to czynniki wchodzące 
w zakres źródeł ekonomicznych powstawania zjawiska terroryzmu. Wyróżnia się trzy rodzaje źródeł ekonomicznych terroryzmu:

— rozpad klas społecznych, stanowiący „bazę terroryzmu”;

- nierównomierny rozwój sił wytwórczych;

- wyzysk ekonomiczny jednej grupy społecznej przez inną ${ }^{22}$.

Kwalifikacja ta nie uwzględnia (przynajmniej w sposób bezpośredni) czynników związanych z postępem techniczno-technologicznym i powinna zostać uzupełniona o ten aspekt. Czynniki te są pośrednio obecne w nierównomiernym rozwoju sił wytwórczych, co wiąże się z nierównym dostępem do nowoczesnych technologii i w efekcie implikuje podziały społeczne.

Nowoczesne technologie nie mogą się obyć bez obecności surowców krytycznych. Rywalizacja w tym zakresie to m.in. dążenie do pozyskania nowoczesnych środków walki, co z kolei przekłada się na zwiększenie efektywności prowadzonych działań, a to uzasadnia zainteresowanie grup terrorystycznych surowcami krytycznymi ${ }^{23}$.

\section{Podsumowanie}

Obserwacja działań wojennych ostatnich kilkunastu lat pozwala stwierdzić, że terroryzm stał się dominującą metodą prowadzenia operacji asymetrycznych. Jego popularyzacja wynika z faktu, że zastosowanie niewielkich środków oddziaływania przy jednoczesnym braku bezpośredniej konfrontacji umożliwia uzyskanie zakładanego efektu bez ponoszenia znacznych strat własnych. Metody terrorystyczne stały się tanim substytutem niemożliwego do osiągnięcia potencjału militarnego i niemilitarnego, niezbędnego do pokonania przeciwnika. Zdaniem autorów metody terrorystyczne wpiszą się na stałe w nowy paradygmat wojny XXI wieku, przyjmując coraz doskonalszą i trudną do przewidzenia formę ataków (zwłaszcza z użyciem nowych technologii) skierowanych na osiąganie celów także w obszarze walki o charakterze ekonomicznym.

\section{Bibliografia}

Adamski J., Nowe technologie w stużbie terrorystów, Warszawa 2007.

Drabik K., Natura wojny w pogladach filozofów realistów, „Kwartalnik Bellona” 2013, nr 3 (674).

Fryc M., Wojna - współczesne oblicze, Toruń 2009.

Gryz J., Terroryzm międzynarodowy jako zjawisko społeczne w początkach XXI wieku, „Zeszyty Naukowe AON" 2016, nr 1 (102) .

Lasota J., Aspekty asymetrii w sztuce wojennej, „Kwartalnik Bellona” 2014, nr 2 (677).

Liedel K., Piasecka P., Współpraca międzynarodowa w zwalczaniu terroryzmu, Warszawa 2004.

22 L. Szmidt, Terroryzm a państwo, Lublin 1979, s. 46.

23 J. Adamski, Nowe technologie w stużbie terrorystów, Warszawa 2007, s. 7. 
Nizińska J., Walka ze soba a walka o siebie, [w:] A. Żuk, Konflikt a walka, Lublin 1996.

Pac B., Integracja wojny informacyjnej i hybrydowej w konfliktach międzynarodowych, „Kwartalnik Bellona" 2016, nr 1 (684).

Reginia-Zacharski J., Ukraina 2014-2015: Wojna (nie)hybrydowa, „Zeszyty Naukowe AON”2015, nr 3 (100).

Skoneczny Ł., Wojna hybrydowa - wyzwanie przyszłości? Wybrane zagadnienia, „Przegląd Bezpieczeństwa Wewnętrznego. Wojna hybrydowa. Wydanie specjalne" 2015.

Stankiewicz W., Ekonomika wojenna, Warszawa 1970.

Szmidt L., Terroryzm a państwo, Lublin 1979.

Szpakowski J., Surowce strategiczne, [w:] Ekonomika obrony, red. W. Bednarek, Łódź 1994.

Wojnowski M., Wojnowski, Mit „,wojny hybrydowej”. Konflikt na terenie państwa ukraińskiego w świetle rosyjskiej myśli wojskowej XIX-XXI wieku, „Przegląd Bezpieczeństwa Wewnętrznego. Wojna hybrydowa. Wydanie specjalne" 2015.

Wrzosek M., Działania psychologiczne w konfliktach nowego wieku, „Kwartalnik Bellona” 2016, nr 2 (685).

Zieliński S., Surowce mineralne, „Chemik” 2014, t. 68, nr 5.

\title{
TERRORISM — DERIVATIVE PHENOMENON OF THE WAR
}

\section{Summary}

In the article a terrorism was shown in three aspects: military, economic and social. Two models of the fight: dynamic and mechanical were related to contemporary conflicts. According to authors of this article, the terrorism is a derivative phenomenon of the war. It is a main reason why we used the mechanical model of the fight to describe the contemporary conflicts.

Keywords: models of the fight, war, terrorism

\author{
Alicja Paluch \\ ala.paluch1@wp.pl \\ Henryk Spustek \\ hspustek@uni.opole.pl
}

